\title{
Risk perception of populations in Northeastern Brazil about domestic sewage treatment and reuse
}

\author{
Douglisnilson de Morais Ferreira \\ Julio Alejandro Navoni \\ André Luis Calado Araújo \\ Viviane Souza do Amaral
}

${ }^{1}$ Post-Graduation in Development and Environment (DDMA), Federal University of Rio Grande do Norte (UFRN)

Natal/RN - Brazil.

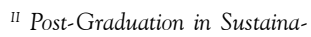
ble Use of Natural Resources (PPgUSRN), Federal Institute in Education, Sciences and Technology of RN (IFRN)

$\mathrm{Natal} / \mathrm{RN}$ - Brasil

D III Federal Institute in Education, Sciences and Technology of RN (IFRN)

Natal/RN - Brazil.

${ }^{\text {IV }}$ Post-Graduation in Development and Environment (DDMA), Federal University of Rio Grande do Norte (UFRN

Natal/RN - Brasil

\begin{abstract}
The reuse is a growing practice in Brazil, given its relevance in minimizing the water scarcity. However, the environmental consequences and its sustainability have not been completely elucidated, being the risk perception analysis a starting point for understanding such concerns. In this perspective, the aim of this study was to evaluate the operation of Sewage Treatment Plants, the applicability of sewage reuse, and its influence on the quality of life of the population of Parelhas and Pedro Velho, counties of the semiarid and northeastern coast, respectively. From the results, it was found a great rejection in the operation of the stations, associated with the impacts produced such as odor and proliferation of mosquitoes, which imply economic, social and public health problems. Regarding reuse, acceptance is predominant for irrigation of crops for human and animal use. We emphasize the need for further research to diagnose the environmental risks arising from this activity.
\end{abstract}

Keywords: Perception; Water reuse; Environmental impacts.

São Paulo. Vol. 23, 2020

Original Article

DOI: http://dx.doi.org/10.1590/1809-4422asoc20180098r1vu2020L4AO 


\section{Introduction}

Water is a natural renewable resource essential for human survival and technological, social and economic development of nations; however, it depends on its quality and availability for use, which are factors closely related to population growth and development. Studies carried out by the National Center for Sustainable Water Supply (NCSWS) estimated that by 2025 population in urban zones may increase by $80 \%$ and that the number of populations suffering with water shortage may be 10 times larger in comparison to nowadays population density (MANCUSO; SANTOS, 2007, p. 16). This is a global issue affecting either arid and semiarid regions where water availability is a limiting factor for human, industrial and agricultural development. Even in regions presenting great water availability, such availability might not be enough to fulfil local demands and likely cause consumption limitations and have negative impact on water quality and economic growth (HESPANHOL, 2007, p. 38-40; ARRUDA, 2011). According to Mota (2002, p. 53), $80 \%$ of the water available in Brazil only supplies approximately $5 \%$ of the population, whereas the remaining $20 \%$ supplies the needs of $95 \%$ of the remaining population - water volume per inhabitant in the Northeastern region is much lower than in other regions.

Accordingly, domestic sewage reuse emerges as alternative to mitigate water shortage and to contribute to economic and regional development, as well as to environmental preservation LU; LEUNG, 2003; MOTA; VON SPERLING, 2009, p. 23). The United States is an example at global sphere, it uses $38 \%$ of the treated sewage in activities of different nature, it has the potential to expand by 5 times its reuse capacity. The National Water Reuse Program in Australia aims at reaching waste use indices higher than 30\% in different activities up to 2020. Besides these two countries, Israel - which accounts for the highest reuse rate in the world - has 70\% of its domestic sewage reused in many areas, including agriculture (EPA, 2012; SCHAER-BARBOSA; SANTOS; MEDEIROS, 2014).

The adoption of reuse practices has been growing in Brazil, mainly in agriculture, fish-farming and animal breeding. Experiments in the Northeastern region involve different federation states and add social, economic and environmental value (QADIR et al., 2010; UCKER et al., 2013). On the other hand, this activity deals with risks to the environment and to public health such as water distribution; and air, soil and irrigated food toxic contamination (URBANO, 2013). Such impacts affect farmers (and their family members) and irrigated food consumers (HESPANHOL, 2007).

Sewage station operations also contribute to worsen the risks; countries such as France, Israel and the United States use advanced treatments to assure the quality and safety of waste selected for reuse. Brazil still deals with treatment stations based on waste stabilization ponds, which have high pathogen (maturation ponds) and organic matter removal (facultative ponds) potential, but little efficiency to eliminate nutrients, salts and organics that, at high concentrations, compromise the quality of crops and soil (MENDONÇA; MENDONÇA, 2017). In many cases, ponds work as sewage storage spaces; therefore, they have high polluting potential, as well as enable mosquito proliferation and unpleasant odor. All these features end up being the cause of rejections shown by the local population, which cannot see the benefits from this treatment technology, not even 
the possibility of using such material in reuse practices (MANCUSO; SANTOS, 2007).

The participation of social actors in identifying risks involved in domestic sewage reuse makes it possible describing the local scene, since there are several factors capable of leading to the acceptance or rejection of this activity. Analysis of perception emerges as the first step to understand socio-environmental issues, because it helps mitigating impacts on the assessed environment (RODRIGUES et al., 2012). Therefore, the aims of the present research were to identify socio-environmental risks resulting from the functioning of Sewage Treatment Stations (STS) and to assess further waste reuse in agriculture based on the analysis of perception applied to residents in Parelhas and Pedro Velho counties, Rio Grande do Norte State (RN), semiarid and coastal regions of Northeastern Brazil, respectively.

\section{Materials and Methods}

\subsection{Study site location}

Parelhas e Pedro Velho, municípios elencados para a realização desta pesquisa, corresParelhas and Pedro Velho counties were chosen for this experiment because they are located in different areas of Rio Grande do Norte State. Parelhas County is located in the Central Potiguar meso-region and in Seridó Eastern micro-region - Northeastern semiarid region - approximately $250 \mathrm{KM}$ from the state capital; it is in the border of Carnaúba dos Dantas, Equador, Jardim do Seridó and Santana do Seridó/RN counties, and of Paraíba State. Pedro Velho County is located in the Southern Coastal microregion, Homogeneous Zone of Eastern Coast Plane, approximately $80 \mathrm{Km}$ from Natal City; it is in the border of Canguaretama, Espírito Santo, Montanhas and Nova Cruz countries, and of Paraíba State.

Parelhas has territorial area of $513.5 \mathrm{~km}^{2}, 21,577$ inhabitants and demographic density of 39.67 inhabitants $/ \mathrm{km} 2$, its climate is semiarid with very hot weather and short rainy season (between March and April). Rainfall is often lower than $600 \mathrm{~mm}$, mean annual relative humidity is of $64 \%$, mean temperature ranges from $28^{\circ} \mathrm{C}$ to $32^{\circ} \mathrm{C}$ and evaporation and insolation rates are high (2,400 annual hours, on average) - which causes water shortage throughout the year. According to the Atlas of Areas Susceptible to Desertification in Brazil (PNUD, 2017), Parelhas' susceptibility to desertification is in a much more severe category. This classification is based on the Dryness Index, which corresponds to the ratio between mean annual rainfall and potential evapotranspiration (MME, 2005; IDEMA, 2008; IBGE, 2010, 2014a; MI, 2017).

Pedro Velho, in its turn, has rainy tropical seasons longer than Parelhas, between January and August; its mean relative humidity is $76 \%$ and annual temperature ranges from $26^{\circ} \mathrm{C}$ to $32^{\circ} \mathrm{C}$, with 2,700 hours of insolation per year. It has territorial area of 192.7 $\mathrm{km} 2$, which corresponds to $0.36 \%$ of the state surface, population close to 14,900 inhabitants and demographic density of 73.2 inhabitants/km2 (IDEMA, 2008; IBGE, 2014).

Industry, agriculture and trading are the main economic highlights in Pedro Velho; 
whereas Parelhas stands out for cheese production, textile industry, ceramics manufacture and the exploration of mineral resources.

Domestic sewage treatment is carried out in a treatment station based on Stabilization Pond System. The treatment station in Pedro Velho stays 700 meters from the urban zone. Thus, sewage is firstly taken to the Elevation Station (EEE) and, subsequently, goes to the STS through repression (CORREIA; GALVÃO; ARAÚJO, 2015). Part of this sewage is used for reuse in beans and maize crops and in elephant grass fields grown for animal feeding. Waste that is not used in irrigation is taken to Curimataú River (the main tributary in the county) through ditches - the river stays approximately 200 meters from the STS, as shown in Figure 1.

Parelhas, in its turn, has two treatment stations; station 2 was the object of the present study. It is located in the downtown area and holds most of the sewage produced in the county (Figure 1). After treatment, sewage is discharged in Seridó River, which is a tributary of Piranhas-Açu River/RN; this river supplies many cities around Parelhas. Sewage flowing in its route to the river is reused in elephant grass fields, and beans and maize crops' irrigation.

Figure 1 - Study site in Parelhas and Pedro Velho counties, Rio Grande do Norte State - Brazil
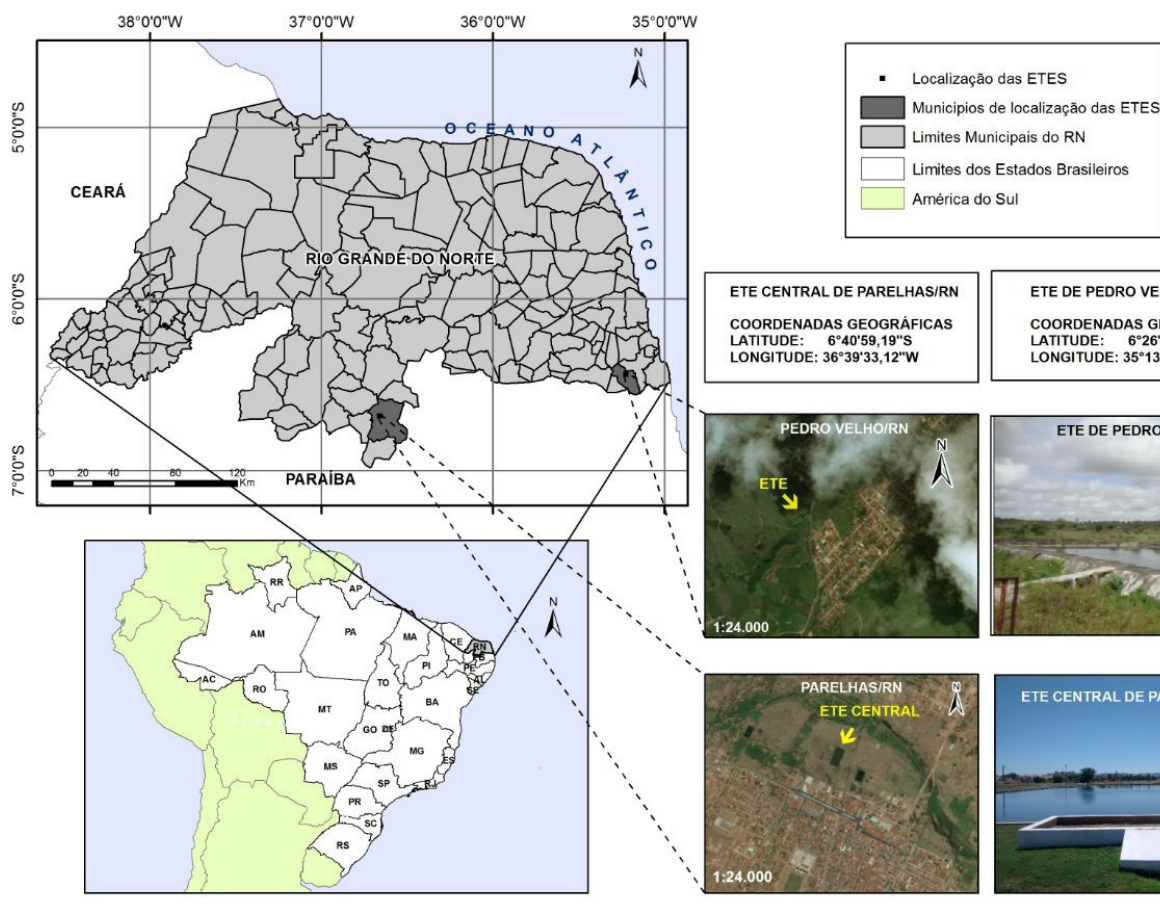

ETE CENTRAL DE PARELHAS/RN COORDENADAS GEOGRÁFICAS LATITUDE: $6^{\circ} 40^{\prime} 59,19^{\prime \prime} \mathrm{S}$
LONGITUDE: $36^{\circ} 39^{\prime} 33,12^{\prime \prime} \mathrm{W}$

ETE DE PEDRO VELHO/RN COORDENADAS GEOGRÁFICAS LATITUDE: $\quad 6^{\circ} 26^{\prime} 21,66^{\prime \prime} \mathrm{S}$
LONGITUDE: $35^{\circ} 13^{\prime} 31,14^{\prime \prime} \mathrm{W}$
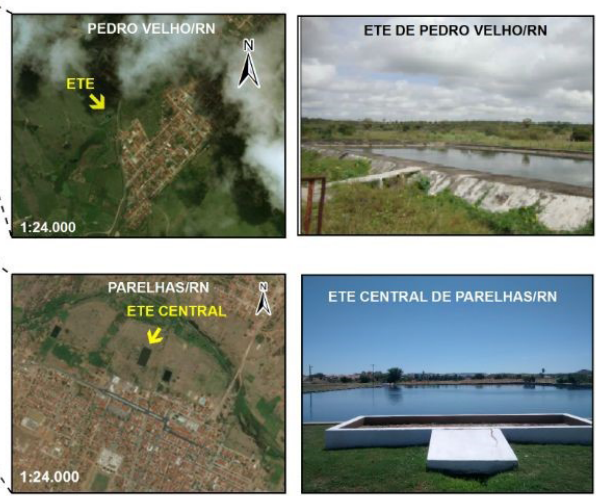

Source: Elaborated by the author 


\section{$3 \quad$ Methodological procedures}

Economic development in the study sites was assessed based on the Human Development Index (HDI) of the county, since it is a representative development indicator. This index comprises three dimensions, namely: longevity, schooling and family income - its score ranges from 0 to 1 ; thus, the closer to 1 , the higher the HDI. This index is divided into 5 levels: very high $(0.800-1.000)$, high $(0.700-0.799)$, moderate $(0.600$ $-0.699)$, low $(0.500-0.599)$ and very low $(0.000-0.499)$ (PNUD, 2017).

Risk perception was carried out through interviews with the population living close to the treatment stations; the collected information was used in content analyses (BARDIN, 2011, p. 47). This evaluation instrument was applied to populations living in areas of great vulnerability due to anthropometric impacts, It was done in order to identify the perception of the local population in these locations based on sensory (vision, hearing, smell and tact) and non-sensory factors (oral transmission, local experiences, reading, mental image, among others) (OLIVEIRA; MACHADO, 2004; PETROVICH; ARAÚJO, 2009). This tool is often adopted to individuals who develop social bonds to the environment they live in; it allows them to build an identity, a sense of belonging to the location and to embody values linked to their way of life (TUAN, 1980, P. 107-108, 129-131).

Questionnaires were applied in Parelhas in June 2016 and in Pedro Velho in March 2017. These questionnaires encompassed 20 closed and opened questions about sociodemographic (sex, age, schooling and time living in the location) and socio-environmental features (STS, its benefits, impacts on the environment and on public health, acceptance to reuse and its applications); they aimed at categorizing responses to make further analysis easier. In total, 100 households were interviewed, they were randomly selected and divided into equal parts in each county. Living less than $1 \mathrm{Km}$ away and being in the age group 18-years or older were the pre-set requirements.

Participants were informed about the scientific profile of the research during the interview, as well as were clarified about the informed and consent form (ICF), which was required by the Ethics Committee of Federal University of Rio Grande do Norte (UFRN), CAAE Certificate n. 54296716.0.0000.5537.

\section{$4 \quad$ Results and Discussion}

Sociodemographic featuring is essential to carry out the perception analysis; it is an HDI indicator of utmost importance to build socio-environmental diagnosis. Pedro Velho stands out for low human development (0.568), it ranks the 4,884th and 152nd national and state positions, respectively. Parelhas, in its turn, has moderate human development (0.676), it ranks the 11th position in $\mathrm{RN}$ and the 2,524th position in the national ranking (IBGE, 2014; PNUD, 2017).

Degree of perception about socio-environmental issues is influenced by the sociodemographic profile of populations participating in the research, as shown in Table 1. 
Table 1 - Sociodemographic data about the global perception of Parelhas and Pedro Velho's population - RN

\begin{tabular}{|c|c|c|c|c|}
\hline \multirow{2}{*}{ Variable } & \multirow{2}{*}{ Categorization } & \multicolumn{3}{|c|}{ Percentage (\%) } \\
\hline & & Global & Parelhas & Pedro Velho \\
\hline \multirow{2}{*}{ Sexo } & Feminino & 62 & 68 & 56 \\
\hline & Masculino & 38 & 32 & 44 \\
\hline \multirow{6}{*}{ Faixa etária (anos) } & $18-20$ & 3 & 02 & 4 \\
\hline & $21-30$ & 15 & 14 & 16 \\
\hline & $31-40$ & 25 & 34 & 16 \\
\hline & $41-50$ & 18 & 12 & 24 \\
\hline & $51-60$ & 21 & 22 & 20 \\
\hline & $>60$ & 18 & 16 & 20 \\
\hline \multirow{5}{*}{$\begin{array}{l}\text { Tempo de residên- } \\
\text { cia no município } \\
\text { (anos) }\end{array}$} & $<5$ & 15 & 22 & 3 \\
\hline & $5-10$ & 11 & 20 & 2 \\
\hline & $11-15$ & 8 & 16 & 2 \\
\hline & $16-20$ & 8 & 08 & 8 \\
\hline & $>20$ & 58 & 34 & 82 \\
\hline \multirow{7}{*}{$\begin{array}{l}\text { Grau de escolari- } \\
\text { dade }\end{array}$} & Sem escolaridade & 5 & 02 & 8 \\
\hline & Fundamental & 32 & 26 & 38 \\
\hline & Fundamental & 11 & 10 & 10 \\
\hline & Médio Incompleto & 2 & 02 & 2 \\
\hline & Médio Completo & 37 & 42 & 32 \\
\hline & Superior Incom- & 5 & 10 & 00 \\
\hline & Superior Completo & 8 & 08 & 10 \\
\hline
\end{tabular}

Source: Elaborated by the author

Most participants were women, approximately $2 / 3$ of the total of interviewees - this finding may be related to the time the survey was carried out (morning and afternoons) and to the prevalence of women in domestic activities - which is a strong feature in counties located in states' hinterlands. Araújo, Souza and Silva (2016) found indices of female participants in a perception analysis carried out in Parelhas' rural conference in the order of $70-80 \%$ - this same trend was also found in research performed by Rodrigues et al. (2012), Correia, Galvão and Araújo (2015) and Suess, Bezerra and Sobrinho (2013). Rodrigues et al. (2012) carried out a perception analysis in the districts of Paranapiacaba, Andreense and Santo André parks, São Paulo Metropolitan Region and recorded 56\% of women in the interviewed sample. Correia, Galvão and Araújo (2015), in their turn, performed a study in Pedro Velho/Rn and found 54\% of women in their sample. Suess, 
Bezerra and Sobrinho (2013) conducted a research in Formosa/GO and observed that women accounted for $55 \%$ of their sample.

In total, $57 \%$ of participants were in the age group 40 -years or older, and this number corroborates the research by de Menezes et al. (2011), Lucena and Freire (2014), Guedes and Amaral (2015) and Araújo, Souza and Silva (2016), who carried out research in counties in Northeastern Brazil; they recorded rates equal to, or higher than, $50 \%$ of individuals in this age group in their sample - this rate was higher than the $60 \%$ recorded for Pedro Velho's sample.

Approximately $60 \%$ of participants in Parelhas have been living in the county for more than 20 years. They helped building the local identity and made it possible developing strong roots and resistance to changes in variable 'Time Living in the County'. This sense of belonging is stronger in Pedro Velho, which recorded rates close to $80 \%$ - except for extreme need situations, such as marriage or professional opportunity, local households often live in the county for their whole life. However, residents tend to take the opposite way, they leave the county to study and work; they migrate to the state capital or to more economically, educationally and socially developed counties. Individuals living in these counties for time shorter than 5 years have migrated from neighbor cities and were encouraged to move due to the aforementioned reasons (LUCENA; FREIRE, 2014).

In total, $82 \%$ of participants completed Elementary school (48\%) and High school (34\%); this information is in compliance with Correia, Galvão and Araújo (2015), Chaves (2015) and Araújo, Souza and Silva (2016), who found rates higher than $80 \%$ for Elementary and High school. Only 13\% of participants had college degree, all of them were women; thus, based on the present perception analysis, this group is quite relevant, since it highlights participants' involvement in rational and decision-making processes (CARVALHO et al., 2011; CHAVES, 2015). Age group, time living in the county and schooling are determining factors for knowledge level, they make local actors passive, lazy and lack critical response to environmental issues experienced in the county (SECTMA, 2009; MENEZES et al., 2011).

Risk perception measured through content analysis comprises a set of evaluation techniques applied to communication. The aim of these techniques is to infer about knowledge on production conditions (or perception) based on qualitative and quantitative indicators (BARDIN, 2011, p. 47). Thus analysis focuses on the men/environment relationship and aims at giving meaning to, and interpretations of, stimuli likely defined through individuals' viewpoint, understanding and communication with the environment; it takes into account the singular ideological influence of each society (WHYTE, 1978; BAY; SILVA, 2011).

Treatment Stations in the assessed counties work based on stabilization pond system, which is broadly used in the country, mainly in the Northeastern region, due to its favorable climatic conditions (sun incidence and temperature) and to the great availability of areas for their installation (VON SPERLING; CHERNICHARO, 2005).

More than $70 \%$ of interviewees in the relative perception analysis about STS functioning have highlighted the importance of treating sewage for local development, 
with emphasis on health, sanitation and quality of life (Graph 1). In households' words, "the station helps the local health and cleaning"; "sewage treatment reduces pollution in the river [...] and avoids sewage discharge on the streets"; "it diminishes the amount of diseases caused by contact with sewage", besides promoting "improvements in the populations' quality of life". With respect to waterbody pollution in Parelhas before the STS became operational, sewage was discharged in Seridó River without any previous treatment, and it used to compromise the quality of the water provided to the population in neighbor counties. Nowadays, sewage is reused in elephant grass fields, and in beans and maize crops; this practice significantly reduces the volume of sewage discharged in waterbodies.

\section{Graph 1 - Perception of residents in Parelhas and Pedro Vel- ho/RN about the positive aspects of STS operations}

\section{ETE IMPORTANCE IN THE COUNTY}

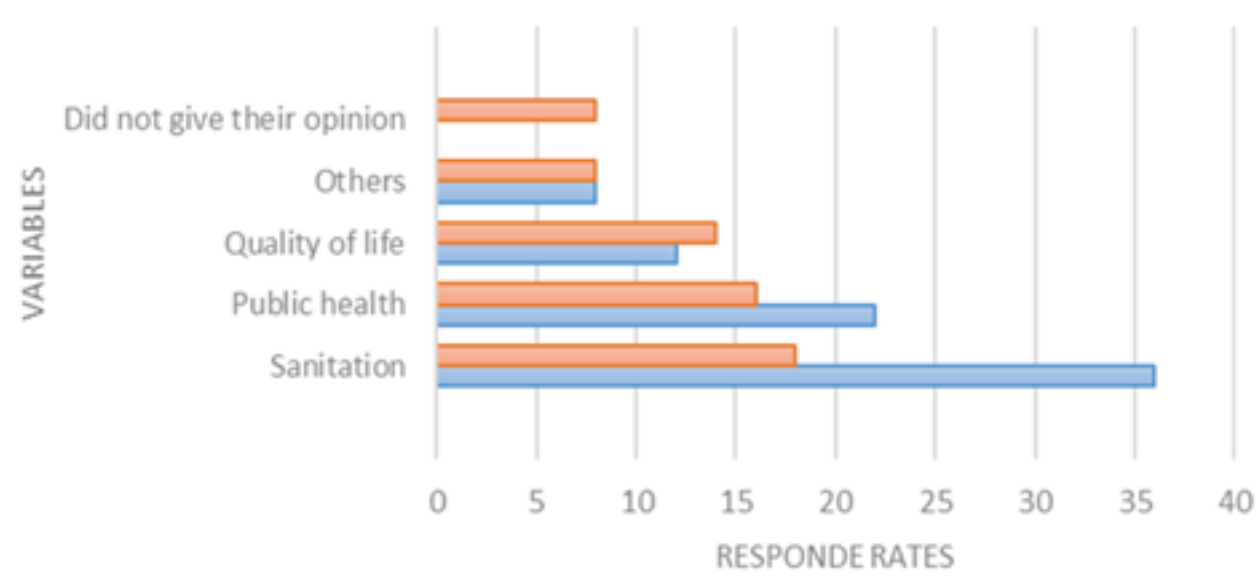

口PEDROVELHO IPARELHAS

Source: Elaborated by the author.

Population dissatisfaction results from station operation flaws. It is possible identifying network leaks in the route between the Elevated Station and the STS in Pedro Velho. There is partial sanitation supply, since houses close to the Station were not yet interconnected to the sewage collection network, as well as constant need of support from the city hall to clean domestic septic tanks. Based on the households, STS "is very important, but it only favors some houses"; "it somehow brought improvements along, accepted for my neighborhood"; "whatever, because it did not bring any benefit to my family". Such reality was diagnosed by Correia, Galvão and Araújo (2015), who found along with local public bureaus - structural and operational issues due to station function- 
ing, which did not imply environmental improvements. Based on interviews conducted in Parelhas, lack of maintenance leads to bad smell and mosquito proliferation, which are factors influencing health, quality of life and local economy.

Approximately $70 \%$ of interviewees understand that some individuals are benefited by the station: $38 \%$ of the total population, $22 \%$ of whom are actually benefited by sanitation; on the other hand, $11 \%$ of the population reported the opposite. This scene is in compliance with households' sense of belonging to the location, which is observed in the herein presented answers: "everybody is benefited because, without the sewage station, sewage would be discharged on the streets". Pedro Velho County recorded high rejection due to high index of participants who are not benefited by sanitation. According to $40 \%$ of interviewees, only part of the city is benefited by sanitation, mainly in the downtown area.

Approximately $20 \%$ of participants in both counties did not give any opinion about the benefit, or not, of the STS. Reasons for such number can be associated with unsafety, locals are afraid to address political topics in research and their reaction makes it clear that some answers evidence the fact that only few households are benefited by sanitation. However, participants rather not express their opinion since they fear some sort of punishment and the worsening of the current scenario.

This behavior is common in perception activities, mainly in rural zones and state hinterlands, such as the case of the research carried out in Amaralina Settlement, Vitória da Conquista/BA, where farmers decided to stay quiet about relevant information associated with environmental impacts from human intervention, since they feared punishments to their activities (GUIMARAES; PAULA, 2013). Toebe et al. (2015) interviewed farmers' children living in Mesorregião, Northeastern Rio Grande do Norte State and observed some factors, such as fear of political prosecution - which can compromise their incomes. It stops their parents from seeking mitigating solutions for the region. They also observed lack of agricultural knowledge, uncertainty about effective law enforcement and affection bonds.

Therefore, the current scene reflects a national reality, mainly in locations where public policies are scarce and there is no legislation and surveillance, which are factors impairing greater advancements in actions to solve the herein presented issues. Yet, it is important highlighting that approximately $60 \%$ of the ones who did not give their opinion have complete elementary school; this finding corroborates the belief about their insecurity and, consequently, about their passive position in face of the experienced environmental issues (SECTMA, 2009; MENEZES et al., 2011).

When interviewees were asked whether station operations offer personal risk, more than half of them stated that economic (real state devaluing, loss of customers by businessman and service providers), affective (the effect of bad smell on family wellbeing) and psycho-social issues (embarrassment, laziness, shame) contribute to the current rejection scene. A perception analysis carried out with the population living close to the STS Paranoá/DF showed that interviewees know impacts caused by the station on the quality of life of the population and on the economic and real estate 
market development, since such impacts imply commercial losses and real estate devaluing (CASTANHEIRA; BAYDUM, 2015) - this situation is similar to that observed in Parelhas and Pedro Velho/RN.

Environmental impacts are factors determining communities' rejection towards STS operations and domestic sewage reuse. Individuals living in Parelhas believe that the treatment is not appropriate, because it leads to different perceptible disorders, such as increased resistance by mosquitos, mainly in the rainy season and at night, as well as terrible smell around the station. Mosquitos become resistant because of the vegetation growing on the edges of the STS and of the long route sewage crosses until reaching the river, as well as of operational flaws in stations, which are associated with local climatic conditions favorable to mosquitos' proliferation (NUVOLARI, 2003, p. 358). Such reality became evident in the research by Freitas et al. (2016), which was conducted in the STS of Pombal County/PB - the main recorded factor was the operationalization of the treatment system.

Bad smell can be associated with great production of cyanobacteria that produce toxins responsible for the bad smell in the tributary, as well as with the solubility of hydrogen sulfide gas, which is inversely proportional to sewage temperature in the station (LILIAMTS; MANCUSO, 2003; CASTANHEIRA; BAYDUM, 2015). Regardless of the toxic gas levels observed in the region, there are many methods to mitigate bad smell caused by sewage treatment; these control strategies can have physical (condensation, adsorption, among others) or biological origin (bio-filters, anaerobic system in the liquid phase) CHERNICHARO et al., 2010; LILIAMTS; MANCUSO, 2003). The applicability and efficiency of environmental remediation processes were corroborated by the perception observed in Pereira Barreto County/SP before and after the implementation of control techniques focused on significantly improving results of the air sensory analysis carried out in the region (LILIAMTS; MANCUSO, 2003).

By comparing the perception, it was possible observing that both counties experience the same issues, namely: leaks in the network during sewage transportation to the stations (ETS, STS) - it allows the formation of smelly sewage puddles in Elevation's surroundings. STS located a little farther from residences have more effective treatments to remove organic matter and coliforms; it is clear that bad smell and mosquito proliferation is not perceptible in these areas. This finding corroborates the study by Araújo et al. (2011), who recorded $66 \%$ of DBO, $71 \%$ of DQO and $99.7 \%$ of thermotolerant coliforms. However, there were small clandestine formations (ponds) of sewage treatment on the route to Curimataú River due to its location; this sewage is reused in beans and maize crops, and in elephant grass fields.

Interviewees related station operation to increase in the number of disease cases, with emphasis on the ones transmitted by vectors such as mosquito species Aedes aegypti (dengue, Chikungunya Fever and Zika Virus), at rates close to 47\% (Parelhas) and 28\% (Pedro Velho), and to diseases caused by terrible smell (32\% and 38\%, respectively) such as malaise, vomiting, headache and chronic issues such as respiratory, heart and neurological diseases (Graphic 2). The aforementioned negative effects can have synergetic 
negative impact on households' quality of life, such as appetite loss, low water consumption and mental distress caused by chronic discomfort (NUVOLARI, 2003 p. 504).

\section{Graph 2 - Impacts of STS operation on population health}

\section{STS IMPORTANCE IN THE COUNTY}

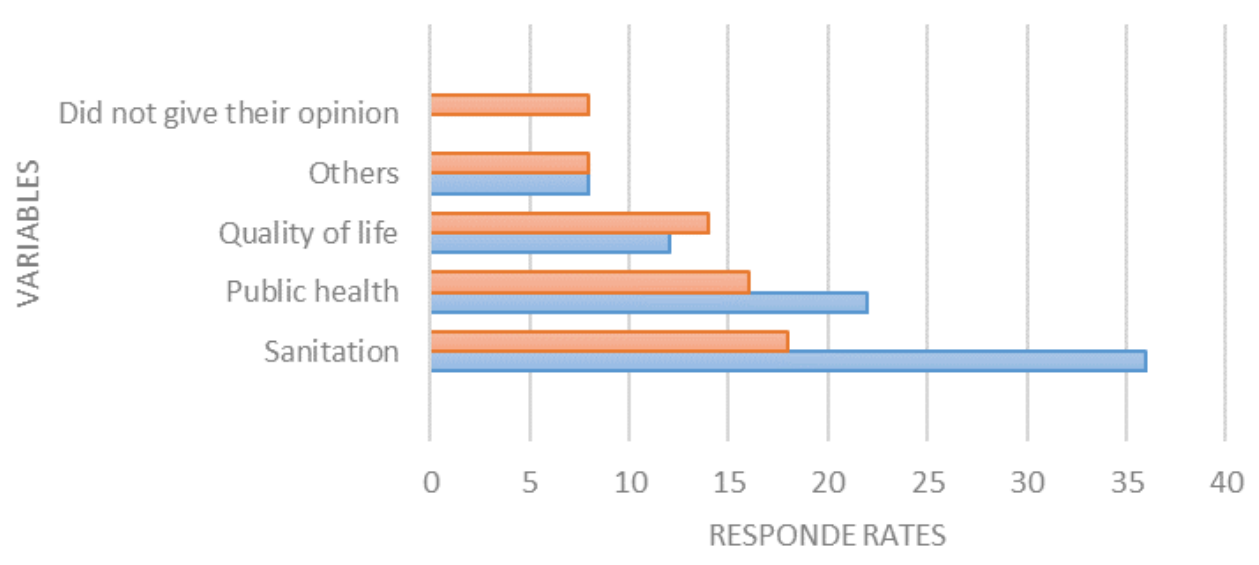

口PEDRO VELHO 口PARELHAS

Source: Elaborated by the author.

The bad smell produced by toxic gases, mainly by hydrogen sulfide $\left(\mathrm{H}_{2} \mathrm{~S}\right)$, is highlighted in the First Aid Guideline of the American Environmental Protection Agency (EPA, 2016), which addresses the toxicity of this gas in humans - iOt can affect vision (tearing, photophobia, blurred vision), smell (loss of odor perception) and tact (skin irritation). Hydrogen sulfide concentrations higher than $10 \mathrm{ppm}$ can cause human health issues on the short-, mid- and long-term, 25\% of interviewees in Pedro Velho stated that the bad smell causes discomfort in the population; in Parelhas, this index is of approximately $60 \%$ - intensity is strong or very strong, mainly at night and in rainy days.

Data provided by the Public Health Secretary and by the Hospital Center of Epidemiological Surveillance of Parelhas presented information about respiratory diseases, with emphasis on 2013 and 2015 (1st trimester), when 30, 66 and 6 cases were recorded, respectively (SESAP, 2017). Lack of information to households about health issues caused by bad smell and about loss of smell associated with lack of diagnosis due to record of toxic gases was observed in the region. These are factors corroborating the current reality, which stops the population to seek medical assistance. Accordingly, air quality monitoring makes it possible diagnosing issues in the local population and their implications to population health.

Natural - high rainfall rates, high temperatures, humidity - and anthropic as- 
pects - lack of sanitation, sewage running free outdoors and station operation without effective treatment, which are features found in the assessed regions - contribute to mosquito proliferation, such as species Aedes aegypti (CORRÊA et al., 2016). Beserra et al. (2009) carried out bio-assay experiments with mosquito larvae and found their longevity in domestic sewage (gross and treated) due to high concentrations of organic matter and nitrogen in it. Larvae lifespan (male) recorded 27 to 30 days (gross and treated sewage) in comparison to the 34 days needed by them in dechlorinated water. Female larvae lasted 46 to 49 days in sewage and 50 days in water, a fact that justifies the need of investigating locations where sewage stations are implemented, as well as the history of diseases caused by mosquitos.

The report by the 2014 Health Surveillance Center of Parelhas addressed 583 suspect dengue cases (NHVE/HDJAD PARELHAS, 2014). In 2015, Parelhas County ranked the 4th position in the state: 431 notified cases; this number was just smaller than those recorded for Natal City - the State Capital $(2,094)$, Currais Novos (529) and Parnamirim (457). The highest index was observed in 2016, given the total of 1,502 suspect dengue cases; this number is three times higher than that recorded the year before. It is important highlighting that back in 2016 Chikungunya and Zika Virus recorded 231 and 07 cases, respectively (SESAP, 2017). Thus, sanitation consequences from environmental changes generated by STS operation can be related to increased number of disease transmissions due to mosquito bite in the county.

If a parallel is drawn between the assessed environmental impacts and HDI, it is possible observing that there are no close relations between them. HDI in Parelhas (0.676) and Pedro Velho (0.568) match the moderate and low human development indices, respectively; it is important having in mind that both counties live their daily lives along with significant environmental issues, as previously mentioned. Such finding is also observed at national scale, including in locations that do not have high HDI rates but that experience similar issues caused by sewage station operations such as in Jaboatão dos Guararapes/PE (IDHM - 0.717), Aparecida de Goiânia/GO (IDHM - 0.718), Pereira Barreto/SP (IDHM - 0.766), Cuiabá/MT and Piracicaba/SP (IDHM - 0.785) (PNUD. 2017). Therefore, impacts resulting from STS implementation and operation affect different social strata. This outcome ratifies observations addressed in the current study about consequences of lack of effective supervision in the country.

Planned gray water reuse is the most effective instrument of water sustainable management, it has been widely grown worldwide and can be applied to industrial, agricultural, leisure and human consumption means - as long as it fulfils each of the expected purposes and quality standards set by the World Health Organization (WHO) or the specific legislation of each country (TOMAZ, 2010; ARRUDA, 2011; EPA, 2012; SCHAER-BARBOSA; SANTOS; MEDEIROS, 2014).

Sewage reuse experience in Brazil concerns different counties in Northeastern Region, which is featured by water shortage. It is possible giving the example of comparative studies about the application of treated sewage to produce green pepper Capsicum annuum L. based on other irrigation forms (well-water and soil with and without fertiliza- 
tion) in Lagoa Seca County/PB. This experiment led to results similar to previous ones recorded for mean fruit weight and leaf area, which have evidenced the effectiveness of this activity (SOUSA et al., 2006). Reuse to irrigate purple elephant grass fields in Pendências County/RN reached mean yield of 130 ton./ha within 160 days; the final product of such reuse was adopted to feed animals and the raw-material was used to produce biomass for power production means (SARAIVA; KONIG, 2013).

It is important listing the advantages of pollution control and environmental impacts, waste recycling and fertilizing saving, since treated sewage is rich in nutrients such as phosphorus and nitrogen. Consequently, it favors agricultural yield due to the rational and sustainable use of water resources, among others. On the other hand, the risks and impacts of sewage reuse go from public health issues, to contamination, and soil and groundwater salinization, as well as to cultures' contamination due to the presence of pathogenic microorganisms and toxic substances in it (BERNARDI, 2003; TELLES; COSTA, 2010).

Population acceptance of sewage reuse is a factor contributing to the development of such activity; thus, the proper STS operation and the local understanding about the benefits of it are factors that make this process easier. Lack of knowledge, distrust and fear, in their turn, are justified by precarious functioning of treatment systems implemented in different social contexts, a fact that corroborates the public opposition to this alternative (SCHAER-BARBOSA; SANTOS; MEDEIROS, 2014).

Although there was great resistance to STS operation in the assessed sites, it is possible observing the perception of the population about the importance of sewage reuse, mainly in agriculture and fish-farming, which can influence the economic and social development in counties like Parelhas. This county presented acceptance indices of $70 \%$ and $40 \%$, respectively; whereas, Pedro Velho recorded $30 \%$ for the same variable and was the county presenting disapproval rates higher than $50 \%$ at any reuse alternative against approximately $20 \%$ in Parelhas. Population knowledge about sanitation alternatives and the operational conditions in stations have significant influence on the recorded answers.

Both counties accepted reuse practices in agriculture for human consumption (beans and maize cultures) and animal feeding (elephant grass), but at limited scope and with low local outspread. Farmers and landowners were the ones who have shown knowledge about the development of this activity, but they believed that it is not for collective use; such understanding leads to lack of interest in its expansion. According to Hespanhol (2008), some factors contribute to population acceptance and involvement in sewage reuse, namely: access to information, trust in interlocutors involved in the project and the concern of the main actors (managers and executors) with environmental issues.

Accordingly, environmental education actions allow actors to broaden and change their values due to environmental potentials and issues (OLIVEIRA et al., 2014) that are of great relevance to the implementation of reuse projects, on their viability, impact, technologies, added warranties and environmental risks (MANCUSO; SANTOS, 2007). Based on the herein carried out perception analysis, the level of interviewees' interest 
in this activity was of approximately $70 \%$. Personal contributions to local development, personal growth and community improvements are the factors encouraging the population to get involved in the implementation process. Individuals who were resistant to the project stated lack of time and interest, as well as limited knowledge to contribute to the project, disbelief in changes and uncertainty about the application of sewage in agricultural practices.

In-depth studies about whether risks to health and the environment can be mitigated by monitoring treated sewage quality and its impacts on agricultural use are necessary. They must also assess the levels of toxic gases in the local atmosphere, as well as apply closer follow-up to treatment efficiency in the stations by system managers and analyze how the outspread of collected information can influence population quality of life and make it possible accomplishing greater sewage reuse alternatives by mitigating water shortage issues in these environments.

\section{$5 \quad$ Final conclusions}

Agricultural reuse of treated sewage has been a practice proven to be useful in mitigating water shortage; it was implemented in many countries that face a situation similar to that experienced in the semiarid region of Northeastern Brazil. It can favor society and the environment; however, the risks of implementing this practice in the assessed locations can be related to environmental, health and socioeconomic issues mostly highlighted by lack of supervision and regulation of this activity.

It is essential having social actors involved in the implementation and supervision processes, as well as of the general population, mainly farmers. First, they must be aware of the social, economic and environmental benefits this activity can bring to the region; second, they must also inform their peers about the impacts it would have on the environment and public health.

Therefore, additional studies are necessary to better understand the real impact of certain activities on the health of populations living in locations influenced by treatment stations, such as monitoring the quality of the treated sewage and the environmental impact of such activity. It is also important regulating the standard quality of this activity in order to make sure of environmental safety and to mitigate potential sanitary consequences of epidemic magnitude.

\section{Acknowledgment}

Thanks to the National Council for Scientific and Technological Development (CNPQ) for the financial support to the research. 


\section{References}

ARAUJO, A. L. C. et al. Avaliação operacional e da eficiência de sistemas de lagoas de estabilização no Rio Grande do Norte. Relatório Final de Pesquisa. Fundação Nacional de Saúde, 2011.

ARAÚJO, J. A. A; SOUZA, R. F.; SILVA, N. M. Percepção sobre mudanças na paisagem de moradores rurais em área suscetível à desertificação na região semiárida do estado do Rio Grande do Norte. Boletim Gaúcho de Geografia, v.43, n. 2: 252-272, 2016.

ARRUDA. V.C.M. Diretrizes para utilização de água de reúso na agricultura: estudo de cenários no semiárido pernambucano. Tese (Doutorado). Programa de Pós-Graduação em Engenharia Civil. Universidade Federal de Pernambuco, Recife, 2011, 173p.

BARDIN, Laurence. Análise de conteúdo. Edição revista e ampliada. Lisboa: Edições 70, 2011.

BAY, A.M.C.; SILVA, V.P. Percepção ambiental de moradores do bairro de liberdade de Parnamirim/RN sobre esgotamento sanitário. v. 3, p. 97-112, 2011.

BERNARDI, C.C. Reúso de água para irrigação. Monografia (Especialização Lato Sensu MBA em Gestão sustentável da Agricultura Irrigada. ISEA-FGV/ECOBUSINESS SCHOOL. Brasília, 2003, 52p.

BESERRA, E. B. et al. Ciclo de vida de Aedes (Stegomyia) aegypti (Diptera, Culicidae) em águas com diferentes características. Iheringia Série Zoologia. Porto Alegre, v. 99, n. 3, p. 281 $285,2009$.

CARVALHO, J. C. N. et al. Tomada de decisão no iowa gambling task: comparação quanto à variável escolaridade. RIPED, v. 2, n. 32, P. 171-186, 2011.

CASTANHEIRA, J. P. A.; BAYDUM, V. P. A. Percepção dos Impactos Socioambientais da Estação de Tratamento de Esgotos (ETE) Relatados pelos Moradores do Residencial Olho d'Água, Jaboatão dos Guararapes, PE. Revista Brasileira de Geografia Física, v.08, n.03, P. 876$887,2015$.

CHAVES, L. C. C. Influência da radiação ionizante natural no açude do boqueirão (RN): avaliação de risco saúde/ambiente. Dissertação (Mestrado). Programa de Pós-Graduação em Desenvolvimento e Meio Ambiente. Universidade Federal do Rio Grande do Norte, Natal, 2015, 73p.

CHERNICHARO, C. A. L. et al. Alternativas para o controle de emissões odorantes em reatores anaeróbios tratando esgoto doméstico. Eng. Sanit. Ambiental, v.15, n.3, p. 229-236, jul-set 2010.

CORREIA, L. A. M. B.; GAlVÃO, M. L. M.; ARAÚJO, A. L. C. Geoprocessamento aplicado a gestão territorial urbana de Pedro Velho/RN. Geoconexões, ano 1, v. 1, P. 44-50, 2015.

CORRÊA, J. A. J. et. al. Associação entre a precipitação pluviométrica e a incidência de dengue em sete municípios do Estado do Pará (Evaluation of logistic regression and neural network models for probabilistic for ecasts of flooding in Curitiba/PR). Revista Brasileira de Geografia Física, v. 9, n. 7, p. 2264-2276, 2016.

EPA - ENVIRONMENTAL PROTECTION AGENCY OF UNITED STATES (USEPA).

Guidelines for Water Reuse. Washington: USEPA, 2012. 
. Secondary Treatment Standards. In: . National Pollutant Discharge Elimination System (NPDES). Disponível em: < https://translate.google.com.br/translate?hl=pt-BR\&sl=en\&u=https://www.epa.gov/npdes\&prev=search >. Acesso em: 10 ago. 2016.

FREITAS, G. P. et al. Sistema de tratamento de efluentes para o campus da Universidade Federal de Campina Grande na cidade de Pombal. Revista Verde de Agroecologia e Desenvolvimento Sustentável, v. 11, n. 2, p. 8-12, 2016.

GOOGLE. Google Earth. Disponível em: https:/earth.google.com/web/. Acesso em: 23 jul. 2018.

GUEDES, J.A.; AMARAL, V.S. Percepção Ambiental das Comunidades Residentes no Entorno do Reservatório Tabatinga, Macaíba/RN. Sociedade e Território, v. 27, no 1, p. 117-137, jan/jun. 2015.

GUIMARAES, S. O ; PAULA, A. Análise da percepção ambiental de produtores rurais do assentamento Amaralina, Vitória da Conquista - BA. Enciclopédia Biosfera: Centro Científico Conhecer. Goiânia, v.9, n. 16, p. 1662-1680, 2013.

HESPANHOL, I. Potencial de reúso de água no Brasil: agricultura, indústria, município e recarga de aquíferos. In: MANCUSO, P. C. S.; SANTOS, H. F. (eds). Reúso de água. 1. Ed. São Paulo: Manole, 2007. 586 p.

HESPANHOL, I. Um novo paradigma para a gestão de recursos hídricos. Estudos Avançados, v.22, n.63, p.131-158, 2008.

INSTITUTO BRASILEIRO DE GEOGRAFIA E ESTATÍSTICA - IBGE. Censo 2010. Características gerais da população, religião e pessoas com deficiências. IBGE: Rio de Janeiro. 2010. $215 \mathrm{p}$.

. Dados estatísticos do RN - 2014. Disponível em: < http://www.ibge.gov.br >. Acesso em: 20 jul. 2017.

INSTITUTO DE DESENVOLVIMENTO DO MEIO AMBIENTE - IDEMA/RN (2008). Perfil do seu município - Parelhas. Disponível em: < http://adcon.rn.gov.br/ACERVO/idema/DOC/ DOC000000000013929.PDF>. Acesso em: 28 abr. 2017.

LILIAMTS, T.B.; MANCUSO, P. C.S. A geração de maus odores na rede coletora de esgotos do município de Pereira Barreto: um problema de saúde pública. Saúde e Sociedade, v.12, n.2, p.86-93, jul-dez 2003.

LU, W; LEUNG, A. Y. T. A preliminary study on potential of developing shower/laundry wastewater reclamation and reuse system. Chemosphere, v. 52, p. 1451-1459, 2003.

LUCENA, M.M.; FREIRE, E.M. Percepção ambiental como instrumento de participação social na proposição de área prioritária no semiárido. INTERthesis, Florianópolis, v.11, n.1, p. 147171, Jan./Jun. 2014.

MANCUSO, P. C. S.; SANTOS, H. F. Conceitos de reúso de água. In: MANCUSO, P. C. S.; SANTOS, H. F. (eds). Reúso de água. 1. reimpressão. São Paulo: Manole, 2007. 586 p.

MENDONÇA, L. C.; MENDONÇA, S.R. Características dos esgotos sanitários. In: MENDONÇA, S. R.; MENDONÇA, L. C. Sistemas sustentáveis de esgotos. 2ª̣ ed. São Paulo: Blucher, 2017, cap. 1, p. 19-59. 
SECRETARIA DE SAÚDE PÚBLICA DO ESTADO DO RN (SESAP): Boletim Epidemiológico. Disponível em: <http://www.saude.rn.gov.br/Conteudo.asp?TRAN=ITEM\&TARG=75 49\&ACT $=\& P A G E=0 \& P A R M=\& L B L=$ Boletins + Epidemiol\%F3gicos. Acesso em: 19 de. 2017.

SOUSA, J. T. et al. Reúso de água residuária na produção de pimentão (Capsicum annuum L.). Revista Brasileira de Engenharia Agrícola e Ambiental, v.10, n.1, p. 89-96, 2006.

SUESS, R. C.; BEZERRA, R.G.; SOBRINHO, H.C. Percepção ambiental de diferentes atores sociais sobre o lago do abreu em Formosa - GO. HOLOS, Ano 29, v. 6, p. 241-258, 2013.

TELLES, D.D. ; COSTA, R.H.P.G. Reúso da água: Conceitos, teorias e práticas. São Paulo: Blucher, 2. ed., 2010.

TOEBE, C. S. et al. Consciência ambiental: o olhar dos filhos de produtores rurais e dos discentes de cursos vinculados às atividades rurais. XX Jornada de Pesquisa - UNIJUI, Porto Alegre, 2015.

TOMAZ, P. Água: pague menos (livro eletrônico). 1a ed. O autor. 2010, 137p. Disponível em: $<$ http://www.pliniotomaz.com.br/downloads/livros/livro_pague_menos/livro_pague_menos. pdf $>$. Acesso em 24 abr. 2017.

TUAN, Yi-Fu. Topofilia - Um Estudo da Percepção, Atitudes e valores do Meio Ambiente. São Paulo: Difel, 1980. 288p.

UCKER, F. E.; et al. Elementos interferentes na qualidade da água para irrigação. Revista Eletrônica em Gestão, Educação e Tecnologia Ambiental. v. 10, n. 10, p. 2102-2111, jan/abr. 2013. URBANO, V.R. Aplicação de água de reúso tratada no cultivo de alface (Lactuca Sativa L.). Dissertação (Mestrado). Universidade Federal de São Carlos - São Carlos, 2013, 87p.

VON SPERLING, M. V.; CHERNICHARO, C. A. L. Biological Wastewater Treatment in Warm Climate Regions, (Vol. 1). IWA Publishing, London, UK, 2005, 1496p.

WHYTE, A. 1978. La perception de L'environnement: lignes directrices méthodologiques pour les études sur le terrain. Notes techniques du MAB 5. Paris: UNESCO, 134 p. 
Douglisnilson de Morais Ferreira

$\square$ moraisdouglisnilson@gmail.com

ORCiD: http://orcid.org/0000-0003-0113-7730

Julio Alejandro Navoni

$\square$ navoni.julio@gmail.com

ORCiD: http://orcid.org/0000-0001-8715-0527

\section{André Luis Calado Araújo}

$\square$ andre.calado@ifrn.edu.br

ORCiD: http://orcid.org/0000-0001-5050-992X

\section{Viviane Souza do Amaral}

๑vi.mariga@gmail.com

ORCiD: http://orcid.org/0000-0002-9326-9054
Submitted on: 26/11/2018

Accepted on: 25/02/2020

2020;23:e00981 


\title{
Percepção de risco no tratamento e reúso de esgotos domésticos em populações do Nordeste
}

\author{
Douglisnilson de Morais Ferreira \\ Julio Alejandro Navoni \\ André Luis Calado Araújo \\ Viviane Souza do Amaral
}

São Paulo. Vol. 23, 2020

Artigo Original
Resumo: O reúso é uma prática crescente no Brasil, dada sua relevância em minimizar a escassez hídrica. No entanto, as consequências ambientais e sua sustentabilidade não têm sido completamente elucidada, sendo a análise da percepção de risco um ponto de partida para entender tais preocupações. Nessa perspectiva, o objetivo deste estudo foi avaliar o funcionamento de Estações de Tratamento de Esgotos, a aplicabilidade do reaproveitamento do esgoto, e sua influência na qualidade de vida da população de Parelhas e Pedro Velho, municípios do semiárido e litoral nordestino, respectivamente. A partir dos resultados, constatou-se grande rejeição no funcionamento das estações, associada aos impactos produzidos como odor e proliferação de mosquitos, os quais implicam em problemas econômicos, sociais e de saúde pública. Quanto ao reúso, predominou-se a aceitação para irrigação de culturas de uso humano e animal. Ressalta-se a necessidade de pesquisas complementares para diagnosticar os riscos ambientais decorrentes dessa atividade.

Palavras-Chave: Percepção; Reúso; Impactos ambientais.

Como citar: FERREIRA, D. M. et al. Percepção de Risco no Tratamento e Reúso de Esgotos Domésticos em Populações do Nordeste. Ambiente $\mathbb{\&}$ Sociedade. São Paulo, v. 23, p. 1-19, 2020.

DOI: http://dx.doi.org/10.1590/1809-4422asoc20180098r1vu2020L4AO 


\title{
Percepción de riesgo en el tratamiento y reutilización de aguas residuales domésticas en poblaciones del Nordeste
}

\author{
Douglisnilson de Morais Ferreira \\ Julio Alejandro Navoni \\ André Luis Calado Araújo \\ Viviane Souza do Amaral
}

São Paulo. Vol. 23, 2020

Artículo original
Resumen: La reutilización es una práctica creciente en Brasil, dada su relevancia para minimizar la escasez de agua. Sin embargo, las consecuencias ambientales y su sostenibilidad no se han dilucidado, siendo el análisis de percepción del riesgo un punto de partida para comprender tales preocupaciones. El objetivo de este estudio fue evaluar el funcionamiento de las plantas de tratamiento de aguas residuales, la aplicabilidad de la reutilización de aguas residuales y su influencia en la calidad de vida de la población de Parelhas y Pedro Velho, respectivamente. A partir de los resultados, se encontró un gran rechazo al funcionamiento de las estaciones asociado con los impactos producidos como olor y la proliferación de mosquitos, que implican problemas económicos, sociales y de salud pública. En cuanto a la reutilización, predominó la aceptación para el riego de cultivos. Se enfatiza la necesidad de más investigación para diagnosticar los riesgos ambientales derivados.

Palabras-Llave: Percepción; Agua de reúso; Impactos ambientales

Como citar: FERREIRA, D. M. et al. Percepción de Riesgo en el Tratamento y Reutilizción de Aguas Residuales Domésticas en Poblaciones del Nordeste. Ambiente \& Sociedade. São Paulo, v. 23, p. 1-19, 2020. 